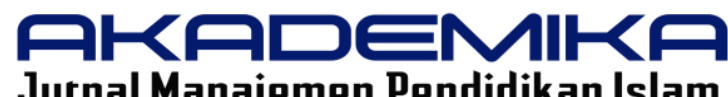

Jurnal Manajemen Pendidikan Islam

INSTITUT AGAMA ISLAM SUNAN KALIJOGO MALANG

P-ISSN 2622-9293 / E-ISSN 2721-9658

Volume 2 Nomor 2 Desember 2020

\title{
KEEFEKTIFAN KEPEMIMPINAN KEPALA SEKOLAH DALAM LEMBAGA PENDIDKAN FORMAL YAYASAN SUNAN KALIJOGO JABUNG
}

\author{
Endang Tyasmaning1) \\ 1)Institut Agama Islam Sunan Kalijogo Malang \\ 1)endang@gmail.com
}

\begin{abstract}
Abstrak: Tujuan dari penelitian ini agar memahami tentang kepemimpinan kepala sekolah yang efektif di lembaga pendidikan formal Yayasan Sunan Kalijogo Jabung, lembaga pendidikan formal dalam penelitian ini mencakup SDS, SMP, SMA, dan SMK Sunan Kalijogo Jabung. Pengumpulan data agar sesuai dengan subjek penelitian maka menggunakan metode kuesioner atau angket. Analisis data kuantitatif dengan menggunakan analisis deskriptif. Subyek dalam penelitian ini yaitu semua kepala sekolah di lembaga pendidikan Yayasan Sunan Kalijogo Jabung. Berdasarkan hasil analisis yang diperoleh melalui penyebaran angket atau kuesioner pada 1) responden inti yaitu keempat kepala sekolah dan 2) responden pendukung yakni seluruh tenaga pendidik dan kependididkan di lembaga pendidikan formal Yayasan Sunan Kalijogo Jabung. Dari hasil angket diperoleh data secara keseluruhan tentang kepemimpinan kepala sekolah yang melalui hasil analisis data dapat disimpulkan bahwa data tentang tingkat efektifitas kepemimpinan kepala sekolah secara umum berada pada kategori sangat baik, sedangkan pada tingkat kualitas kepemimpinan kepala sekolah dapat dikualifikasikan dengn kategori baik atau 75\%.
\end{abstract}

Kata Kunci: kepala sekolah, kepemimpinan, Yayasan Sunan Kalijogo Jabung

Abstract: The purpose of this study is to understand the effective leadership of the principal in the formal educational institutions of the Sunan Kalijogo Jabung Foundation, the formal education institutions in this study include SDS, SMP, SMA, and SMK Sunan Kalijogo Jabung. Collecting data to fit the research subject then using a questionnaire or questionnaire method. Quantitative data analysis using descriptive analysis. The subjects in this study were all school principals at the Sunan Kalijogo Jabung educational institution. Based on the results of the analysis obtained through distributing questionnaires to 1) core respondents, namely the four school principals and 2) supporting respondents, namely all educators and staff in formal educational institutions of the Sunan Kalijogo Jabung Foundation. From the results of the questionnaire, the overall data obtained about the leadership of school principals, through the results of data analysis, it can be concluded that the data on the level of effectiveness of principal leadership in general are in the very good category, while at the level of leadership quality the principal can be qualified with the good category or $75 \%$.

Keywords: school principal, leadership, Sunan Kalijogo Jabung Foundation 


\section{A. LATAR BELAKANG}

Banyak sekali permasalahan yang muncul dalam sistem pendidikan di Indonesia, salah satu permasalahan pendidikan yang dihadapi oleh bangsa Indonesia adalah rendahnya mutu pendidikan yang ada pada setiap jenjang dan satuan pendidikan. Berbagai usaha untuk menyelesaikan permasalahan itu telah dilakukan oleh pemerintah agar berhasil meningkatkan mutu pendidikan nasional, beberapa usaha yang dilakukan antara lain: 1) pengembangan kurikulum nasional dan lokal, 2) peningkatan kompetensi guru melalui pelatihan, 3) pengadaan buku dan alat pelajaran, 4) pengadaan dan perbaikan sarana dan prasarana pendidikan, dan 5) peningkatan mutu manajemen sekolah dengan cara meningkatkan kualitas kepala sekolah. Dalam dunia pendidikan, aspek kepemimpinan merupakan sistem kepemimpinan yang dilakukan oleh seseorang di suatu sekolah. Sekolah sebagai unit kerja dan lembaga pendidikan formal dipimpin oleh seorang kepala sekolah. Hal ini membuat kepemimpinan seorang kepala sekolah menjadi hal utama dalam keberlangsungan suatu sekolah. Agar dapat bersaing di era 4.0, maka dibutuhkan kepala sekolah yang profesional dalam bidangnya. Kepala sekolah profesional bisa mencakup tentang sifat-sifat, perilaku pribadi, pengaruh terhadap orang lain, pola interaksi, kerjasama antar pelaku, kedudukan dari satu jawaban administratif, dan persepsi dari lain-lain tentang legitimasi pengaruh.

Betapa perlunya kualitas kepemimpinan kepala sekolah, maka selalu ditekankan pentingnya tiga kemampuan dasar yang perlu dimiliki oleh kepala sekolah, yaitu: 1) conceptual skills, 2) human skills, 3) technical skills. Kepala sekolah diharapkan mampu memahami dan menerapkan ketiga macam keterampilan dasar tersebut, selain itu kepala sekolah juga diharapkan mampu: 1) menentukan tujuan sekolah, 2) mengorganisasikan atau mengatur sekolah, 3) menanamkan pengaruh atau kewibawaan kepemimpinannya, d) memperbaiki pengambilan keputusan, dan e) melaksanakan perubahan (perbaikan) pendidikan. Tiap-tiap teori dan definisi di atas sinkron dengan pendekatan-pendekatan yang diusahakannya. 
Pondok pesanten sunan kalijogo jabung-malang, yang didirikan oleh K.H. Nur Salim (Gus Nur) pada tahun 60-an. Pondok pesantren ini diawali dengan pembangunan gubuk kecil sebuah tempat "istirahat" dan sholat yang lebih sering disebut dengan "wakaf" yang terletak dipinggir sungai kecil di dusun Gandon Timur desa sukolilo. Pada tahun 80-an pesantren Sunan Kalijogo membuka beberapa kegiatan keagamaan, seperti pembacaan Manaqib Qubro (manaqib syekh Abdul Qodir al-Jailani) yang dilaksanakan setiap malam minggu Pon. Nama K.H. Nur Salim memang cukup dikenal dengan sosok yang loman (dermawan). Kharismatik dan beliau cukup disegani dan dikenal dengan pedomannya "sabar, ngalah, neriman, loman". Kemudian semenjak KH Nur Salim wafat (sekitar tahun 1998) pesantren Sunan Kalijogo diasuh oleh putra beliau yakni Gus H. Ali Muzaki, sistem pesantren dikembangkan dengan tidak meninggalkan tradisi lama dari sang ayah, beliau memadukan dengan sistem pendidikan yang beliau tempuh di Pesantren Ngalah yang merupakan milik mertua beliau yakni KH Sholeh Bahrudin, dengan membuka pondok pesantren putri lalu dikembangkan dengan menambahkan model Madrasah Diniyah, serta Taman Pendidikan Quran (TPQ) metode qira'ati. Pondok Pesantren ini terus berkembang dengan berbagai pendidikan formal antara lain: SDS, SMP, SMA, SMK, Sunan Kalijogo Jabung dan sebuah Perguruan Tinggi Institut Agama Islam Sunan Kalijogo Malang. Tiap sekolah dalam Yayasan Sunan Kalijogo Jabung dipimpin oleh kepala sekolah yang telah ditunjuk langsung oleh pengurus yayasan dan disetujui oleh pengasuh pondok pesantren yakni Gus H. Ali Muzaki. Semua kepala sekolah tersebut dipilih berdasarkan kompetensi, loyalitas, dan profesional mereka dalam bekerja, sebab menjadi kepala sekolah merupakan tanggung jawab yang besar dalam proses dan pengembangan pendidikan di sekolah. Kepemimpinan kepala sekolah yang profesional akan membawa dampak yang positif bagi sekolah khususnya dan bagi yayasan pada umumnya. Karena pentingnya suatu kepemimpinan kepala sekolah dalam suatu lembaga pendidikan formal khususnya di Yayasan Sunan Kalijogo Jabung, maka perlu diadakan suatu penelitian yang memberikan pemahaman dan informasi tentang kepemimpinan kepala sekolah di tiap lembaga formal Yayasan Sunan 
Kalijogo Jabung, sehingga dapat memebrikan solusi tentang berbagai permasalahan yang ada dalam suatu kepemimpinan yang telah diterapkan. Untuk itu diperlukan berbagai pendekatan yang sesuai dengan permasalahan tersebut. Indrafachrudi (2006). Menyatakan bahwa "Berbagai pendekatan itu adalah untuk memecahkan permaslahan-permasalahan kepemimpinan yang telah lama dilakukan dan diselidiki oleh para ahli." Agar permasalahan tentang kepemimpinan kepala sekolah dapat diketahui dan diberikan solusi yang tepat, maka dibutuhkan suatu penelitian di lembaga pendidikan formal yang ada di Yayasan Sunan Kalijogo Jabung.

Penelitian ini dilaksanakan dalam kurun waktu satu tahun yakni tahun pelajaran 2018-2019, dalam penelitian ini yang menjadi subjek penelitian adalah semua kepala sekolah pada lembaga pendidikan formal SDS, SMP, SMA dan SMK yang bernaung di bawah Yayasan Sunan Kalijogo Jabung. Berdasarkan analisis situasi dalam latar belakang tersebut, maka dapat dirumuskan permasalahan dalam penelitian ini yaitu:

1. Bagaimana bentuk profesionalisme kepemimpinan kepala sekolah di lembaga pendidikan formal SDS, SMP, SMA, SMK Sunan Kalijogo Jabung?

2. Seperti apa permasalahan yang muncul dalam kepemimpinan kepala sekolah di lembaga pendidikan formal SDS, SMP, SMA, SMK Sunan Kalijogo Jabung?

3. Dilaksanakannya penelitian ini bertujuan memeroleh pemahaman tentang bentuk profesionalisme dan permasalahan yang muncul dalam kepemimpinan kepala sekolah yang diterapkan dalam lembaga pendidikan formal SDS, SMP, SMA, SMK Sunan Kalijogo Jabung?

\section{B. KAJIAN TEORI}

\section{Kepemimpinan Kepala Sekolah}

Seorang pemimpin memiliki peranan yang penting dalam menggerakkan keberlangsungan suatu lembaga atau organisasi. Menurut Winardi, pemimpin adalah seorang yang karena kecakapan-kecakapan pribadinya dengan atau tanpa pengangkatan resmi dapat mempengaruhi kelompok yang dipimpinnya untuk 
mengerahkan usaha bersama ke arah pencapaian sasaran atau tujuan bersama ${ }^{1}$. Berdasarkan pendapat tersebut dapat dipahami bahwa pemimpin adalah seseorang yang mampu mewujudkan suatu visi misi dan memiliki kemampuan untuk menggerakkan, membimbing, memimpin dan memberi kegairahan kerja terhadap orang lain. Jadi bila ditarik kesimpulan dari pendapat di atas, pemimpin adalah orang yang dapat mempengaruhi, menggerakkan, menumbuhkan perasaan ikut serta dan tanggung jawab, memberikan fasilitas, tauladan yang baik serta kegairahan kerja terhadap orang lain.

Kepemimpinan diterjemahkan ke dalam istilah sifat-sifat, perilaku pribadi, pengaruh terhadap orang lain, pola-pola interaksi, hubungan kerja sama antar peran, kedudukan dari suatu jabatan administratif, dan persepsi lain tentang legitimasi pengaruh. ${ }^{2}$ Dapat disimpulkan bahwa pengertian kepemimpinan adalah suatu kegiatan dalam membimbing suatu kelompok sedemikian rupa sehingga tercapailah tujuan kelompok itu. Tujuan tersebut merupaka tujuan bersama. Dalam usaha untuk mencapai tujuan berama itu, pemimpin dan kelompok yang satu bergantung pada kelompok dan pemimpin yang lain. Seseorang tidak dapat menjadi pemimpin terlepas dari kelompok. Kepemimpinan merupakan suatu sifat dari kelompok. Setiap orang sebagi anggota suatu kelompok dapat memberikan sumbangannya untuk kesuksesan kelompoknya.

Indrafachrudi berpendapat bahwa kepemimpinan adalah suatu kegiatan dalam membimbing suatu kelompok sedemikian rupa sehingga tercapailah tujuan kelompok itu, tujuan tersebut merupakan tujuan bersama ${ }^{3}$. Sedangkan Hanurawan, (2002: 34) Kepemimpinan dapat didefinisikan sebagai kategori perilaku yang dapat membuat seseorang (pemimpin) mampu mempengaruhi orang lain." Mengingat tugas kepemimpinan yang kompleks, pengertian kepemimpinan tidak dapat dibatasi secara pasti, termasuk pengertian kepemimpinan efektif di sekolah. Cara-cara seorang

\footnotetext{
${ }^{1}$ Winardi, J. 2004. Manajemen Perilaku Organisasi. Jakarta: Prenada Media. Hlm.304.

2 Wahyosumidjo. 2007. Kepemimpinan Kepala Sekolah. Jakarta: PT Raja Grafindo Persada. hlm.37

${ }^{3}$ Indrafachrudi, S. 2006. Bagaimana Memimpin Sekolah yang Efektif. Bogor : Ghalia Indonesia. hlm.45
} 
pemimpin melaksanakan kepemimpinannya berbeda-beda. Kepala sekolah dalam melaksanakan kepemimpinan hendaklah menggunakan pengetahuan, pengalaman, dan sifat kepemimpinan. Sehubungan dengan itu, kepala sekolah dituntut memiliki kemahiran dan keterampilan dalam mengelola lembaga pendidikan. Ada beberapa macam keterampilan, yaitu: 1) keterampilan memimpin, 2) keterampilan menjalin hubungan kerja sama dengan sesama manusia, 3) keterampilan menguasai kelompok, 4) keterampilan mengelola administrasi personalia, 5) keterampilan menilai ${ }^{4}$.

Kepala Sekolah menjadi salah satu aspek penting dalam keberlangsungan suatu proses perkembangan sekolah, sebab peranan kepala sekolah sebagai suatu pemimpin utama dalam suatu sekolah yang menjadi penentu, pemberi keputusan, pada hal-hal krusial berkaitan sekolah, dan menjadi pengayom bagi warga sekolah secara intern. Wahjosumidjo mendefinisikan bahwa Kepala Sekolah sebagai seorang tenaga fungsional guru yang diberi tugas untuk memimpin suatu sekolah dimana diselenggarakan proses belajar mengajar, atau tempat dimana terjadi interaksi antara guru yang memberi pelajaran dan murid sebagai penerima pelajaran. ${ }^{5}$ Namun banyak faktor penghambat tercapainya kualitas keprofesionalan kepemimpinan kepala sekolah seperti proses pengangkatannya tidak transparan, rendahnya mental kepala sekolah yang ditandai dengan kurangnya motivasi dan semangat serta kurangnya disiplin dalam melakukan tugas, selain itu seringnya datang terlambat, wawasan kepala sekolah yang masih sempit, serta banyak faktor penghambat lainnya yang menghambat tumbuhnya kepala sekolah yang professional untuk meningkatkan kualitas pendidikan. Ini mengimplikasikan rendahnya produktivitas kerja kepala sekolah yang berimplikasi juga pada mutu (input, proses, dan output). Kepala sekolah merupakan suatu kekuatan efektif dalam pengelolaan sekolah yang berperan bertanggung jawab dalam menghadapi perubahan, sehingga mampumembuat para guru, staf, dan siswa menyadari akan tujuan sekolah yang telah ditetapkan, dengan

\footnotetext{
${ }^{4}$ Ibid

${ }^{5}$ Wahyosumidjo. 2007. Kepemimpinan Kepala Sekolah. Jakarta: PT Raja Grafindo Persada. Hlm.83
} 
kesadaran tersebut para guru, staf dan siswa dengan penuh semangat melaksanakan tugas masing-masing dalam mencapai tujuan sekolah. Menurut Wahjosumidjo kepala sekolah merupakan dua gabungan kata, kedua kata terebut adalah "kepala" dan "sekolah". Kata kepala dapat diartikan "ketua" atau "pemimpin" dalam suatu organisasi atau sebuah lembaga. Sedangkan "sekolah" adalah sebuah lembaga dimana menjadi tempat menerima dan memberi pelajaran. ${ }^{6}$

Dari definisi di atas dapat menarik kesimpulan bahwa kepala sekolah adalah seseorang yang ditunjuk sebagai pemimpin di satuan pendidikan. Pemimpin ada dua macam, yaitu 1) pemimpin formal dan 2) pemimpin nonformal. Pemimpin formal, artinya dia diangkat secara formal (formally designated leader) oleh organisasi yang bersangkutan atau organisasi yang menjadi atasannya. Sehingga secara organisatoris mempunyai tugas membina, membimbing, memberi bantuan dan dorongan kepada staf sekolah untuk mencapai tujuan yang ingin dicapai. Siapapun yang akan diangkat menjadi kepala sekolah harus ditentukan melalui prosedur serta persyaratanpersyaratan tertentu.

Beberapa rujukan menjelaskan bahwa kepemimpinan efektif di sekolah dapat berkait dengan kepemimpinan kepala sekolah di sekolah yang efektif. Atas dasar pandangan ini, maka kepemimpinan efektif di sekolah dapat dimengerti sebagai bentuk kepemimpinan yang menekankan kepada pencapaian prestasi akademik dan non akademik sekolah. Sebagai pemimpin pendidikan di sekolah, kepala sekolah memiliki tanggung jawab legal untuk mengembangkan staf, kurikulum, dan pelaksanaan pendidikan di sekolahnya. Efektifitas kepemimpinan kepala sekolah tergantung dari kemampuannya bekerja sama dengan guru dan staf, serta mengendalikan pengelolaan anggaran, pengembangan staf, scheduling, pengembangan kurikulum, pedagogik, dan asesmen. Membekali kepala sekolah memiliki seperangkat kemampuan ini dirasa sangat penting. Indrafacrudi menjelaskan dalam bukunya “pada dasarnya dapat fungsi kepemimpinan pendidik dibagi atas dua macam, yaitu: a)

\footnotetext{
${ }^{6}$ Ibid
} 
fungsi yang bertalian dengan tujuan yang hendak dicapai, b) fungsi yang bertalian dengan penciptaan suasana pekerjaan yang sehat dan menyenangkan sambil memeliharanya. Hasil penyelidikan Tead (dalam Indrafachrudi, 2006) dianggap penting sekali bagi kepemimpinan pendidikan. Ia menyarankan sifat kepemimpinan pendidikan sebagai berikut: (a) memiliki kesehatan jasmaniah dan rohaniah yang baik, (b) berpegang teguh pada tujuan yang hendak dicapai, (c) bersemangat, (d) jujur, (e) cakap dalam memberi bimbingan, (f) cepat serta bijaksana dalam mengambil keputusan, (g) cerdas, dan (h) cakap dalam hal mengajar dan menaruh kepercayaan pada yang baik dan berusaha mencapainya. ${ }^{7}$

Berdasarkan uraian di atas dapat disimpulkan bahwa Kepala Sekolah merupakan seorang guru yang mendapat tugas tambahan sebagai Kepala Sekolah yang paling betanggung jawab terhadap aplikasi prinsip-prinsip administrasi pendidikan yang inovatif di sekolah. Sebagai orang yang mendapatkan tugas tambahan berarti tugas pokok Kepala Sekolah tersebut adalah guru yaitu sebagai tenaga pengajar dan pendidik, maksudnya dalam suatu sekolah seorang Kepala Sekolah harus mempunyai tugas sebagai seorang guru yang melaksanakan atau memberikan pelajaran atau mengajar bidang studi tertentu atau memberikan bimbingan. Berarti dalam hal ini, Kepala Sekolah memiliki dua fungsi yaitu sebagai tenaga kependidikan dan tenaga pendidik. Selain itu sebagai kepala sekolah dia juga berperansebagai pemimpin, jadi kepemimpinan kepala Sekolah diharapkan dapat menciptakan suasana dan lingkungan agar tetap kondisi supaya memungkinkan terwujudnya iklim kerja dan hubungan antar manusia selalu harmonis dan kondusif. Hal ini berarti bahwa seluruh komponen pendidikan di sekolah harus dikembangkan secara terpadu antara Kepala Sekolah dengan tenga pendidik dan kependidikan yang lainnya dalam rangka meningkatkan relevansi serta kesesuaian peningkatan kualitas pendidikan.

\footnotetext{
${ }^{7}$ Indrafachrudi, S. 2006. Bagaimana Memimpin Sekolah yang Efektif. Bogor : Ghalia Indonesia. hlm.3
} 


\section{METODE PENELITIAN}

Metode penelitian yang digunakan dalam penelitian ini yakni metode deskriptif kualitatif. Metode penelitian kualitatif deskriptif digunakan untuk memberikan informasi yang detail dan terperinci sehingga dapat memberikan solusi pada berbagai permasalahan yang menjadi sumber permasalahan. Metode penelitian ini menuturkan, menganalisa, dan mengklasifikasi dengan cara 1) menyelidiki dengan teknik survey, 2) interview, 3) angket, 4) observasi, dan 5) teknik test. Jadi dapat dipahami bahwa metode deskriptif ini adalah sebuah metode yang menjabarkan dan menafsirkan data yang telah ditemukan atau diketahui. Tujuan utama metode ini adalah untuk memahami fenomena atau gejala sosial dengan lebih menitik beratkan pada gambaran yang lengkap tentang fenomena yang dikaji daripada memerincinya menjadi variabel-variabel yang saling terkait. Harapannya ialah diperoleh pemahaman yang mendalam tentang fenomena untuk selanjutnya dihasilkan sebuah teori. Karena tujuannya berbeda dengan penelitian kuantitatif, maka prosedur perolehan data dan jenis penelitian kualitatif juga berbeda.

Peneliti berusaha memberikan sudut pandang mengenai permasalahan yang diteliti dengan cara menginterpretasikan kejadian dan peristiwa sosial sesuai dengan sudut pandang dari objek penelitian berdasarkan temuan data yang telah terkumpul. Dalam penelitian kualitatif, peneliti itu sendiri bertindak sebagai instrumen penelitiannya; yang mana sebagai instrumen penelitian peneliti harus memiliki bekal teoridan wawasan yang luas, sehingga mampu bertanya, menganalisis, memotret danmengkonstruksi situasi sosial yang diteliti menjadi lebih jelas dan bermakna (Sugiono, 2008). Hal ini juga sesuai dengan pendapat yang dinyatakan oleh (Margono: 2004) bahwa dengan karakteristik penelitiannya yang holistik (menyeluruh), peneliti dalam penelitian kualitatif memerlukan ketajaman analis (bersifat deskriptif analitik), objektifitas, sistematik dansistemik sehingga diperoleh ketepatan dalam interpretasi. Berdasarkan jenis penelitiannya, maka penelitian deskriptif ini memberikan hasil penelitian dalam bentuk uraian yang objektif dan sesuai dengan kondisi objek penelitian sebagai acuan untuk memberikan solusi terhadap permasalahan yang 
dihadapi. Arikunto (2007: 115) menjelaskan bahwa "populasi adalah keseluruhan subyek penelitian" Berdasarkan definisi tersebut, maka yang menjadi populasi dalam penelitian ini yaitu seluruh kepala sekolah yang berada di bawah naungan Yayasan Sunan Kalijogo Jabung, dengan jumlah populasi adalah sebanyak 4 kepala sekolah yang memimpin lembaga pendidikan SD, SMP, SMA, dan SMK Sunan Kalijogo Jabung. Sampel penelitian menurut Arikunto sebagian atau wakil populasi yang diteliti. ${ }^{8}$ Sementara Hadi (1987: 221) berpendapat bahwa sampel sebagai "sejumlah penduduk yang jumlahnya kurang dari populasi. ${ }^{9}$ Karena sedikitnya jumlah populasi maka yang dijadikan sampel dalam penelitian ini adalah keempat kepala sekolah yang memimpin ditiap sekolah pada Yayasan Sunan Kalijogo Jabung.

Data yang objektif dibutuhkan untuk memahami permasalahan yang sedang diteliti. Dalam memeroleh data yang sesuai dengan subjek penelitian dibutuhkan sebuah instrumen yang tepat dan relevan dengan permasalahan. Menurut Arikunto instrumen penelitian adalah alat atau fasilitas yang digunakan oleh peneliti dalam mengumpulkan data agar pekerjaannya lebih mudah dan hasilnya lebih baik, dalam arti lebih cermat, lengkap, dan sistematis sehingga lebih mudah diolah. ${ }^{10}$ Sesuai dengan permasalahan yang diteliti maka Instrumen yang diguna kan dalam penelitian ini adalah angket. Angket merupakan suatu cara pengumpulan data dengan menyebarkan sejumlah pertanyaan berdasarkan permasalahan penelitian. Arikunto menjelaskan bahwa Angket atau kuisioner adalah sejumlah pertanyaan yang digunakan untuk memperoleh informasi dari responden dalam arti laporan tentang pribadinya atau hal hal lain yang ia ketahui. ${ }^{11}$ Angket yang digunakan dalam penelitian ini ada dua model yaitu: 1) angket model A untuk responden inti berisi 35

\footnotetext{
${ }^{8}$ Arikunto, S. 2006. Prosedur Penelitian Suatu Pendekatan Praktek. Jakarta: PT. Rineka Cipta.hlm.104.

${ }^{9}$ Hadi, S. 1987. Statistik II. Yogyakarta: YPFP UGM.

${ }^{10}$ Arikunto. Op.cit. hlm.106.

${ }^{11}$ Ibid. hlm.139.
} 
pertanyaan dengan 5 opsi jawaban, dan 2) angket model B untuk responden pendukung berisi 25 pertanyaan dengan 5 opsi jawaban.

Responden dalam penelitian ini dibagi menjadi dua bagian, yaitu: 1) responden inti yang terdiri dari keempat kepala sekolah, dan 2) responden pendukung yang mencakup 123 orang tenaga pendidik dan kependidikan di keempat sekolah yakni SD, SMP, SMA, dan SMK Sunan Kalijogo Jabung yang sudah menjadi pegawai tetap yayasan dan telah bekerja minimal 5 tahun.

Data yang telah terkumpul perlu dilakukan analisis data yang akurat, untuk itu dalam penelitian ini peneliti menggunakan analisis data kualitatif, yaitu dengan cara:

1) Reduksi data, yaitu peneliti memilih dan memilah-milah data yang akan dianalisis berupa hasil jawaban angket yang telah disebarkan kepada semua responden.

2) Data display, yaitu peneliti menampilkan data yang telah dipilih dan dikelompokkan sesuai dengan jawaban yang tertulis.

3) Verifikasi data, yaitu penulis menyimpulkan hasil analisis data berdasarkan hasil analisis yang telah dilakukan dengan cara mendeskripsikan secara detail dan terperinci.

\section{PEMBAHASAN}

\section{Kepemimpinan Kepala Sekolah yang Efektif pada Lembaga Pendidikan Formal Yayasan Sunan Kalijogo Jabung}

Berdasarkan 2 model angket tentang keefektifan kepemimpinan kepala sekolah yang telah disebarkan kepada semua responden yaitu model A untuk responden inti yakni kepala sekolah. Dari angket model A yang terdiri dari 35 pernyataan dan 5 alternatif jawaban, diperoleh data data tentang kepemimpinan kepala sekolah yang efektif sebanyak 3 responden atau 75\% tergolong kategori Sangat Baik, sedangkan 1 responden atau 25\% tergolong Baik. Sedangkan berdasarkan angket model B untuk responden pendukung yang telah disebarkan kepada responden inti yakni pendidik dan tenaga kependidikan sebanyak 123 orang di lembaga pendidikan SD, SMP, SMA, dan SMK yang bernaung di bawah Yayasan 
Sunan Kalijogo Jabung Kabupaten Malang, maka diperoleh data keseluruhan tentang kepemimpinan kepala sekolah yang efektif dengan rincian 102 responden atau 82\% memberikan penilaian Sangat Baik dan 21 responden atau 18\% memberikan penilaian Baik. Berdasarkan hasil dari 2 model angket tersebut dapat disimpulkan bahwa kepemimpinan kepala sekolah di setiap lembaga pendidikan formal SD,SMP, SMA, dan SMK Sunan Kalijogo Jabung tergolong dalam kategori keefektifan yang Sangat Baik.

ANGKET A

- Sangat Baik = Baik =Cukup Baik $=$ Kurang Baik

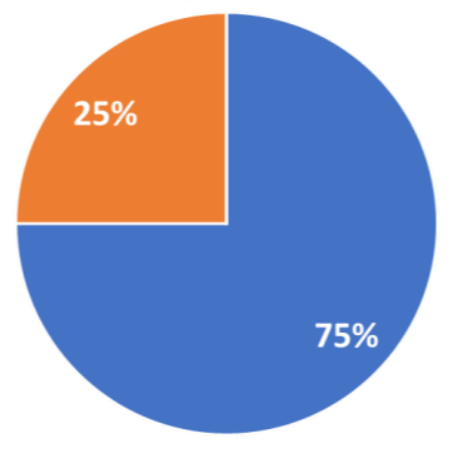

ANGKET MODEL B

- Sangat Baik = Baik =Cukup Baik = Kurang Baik =Tidak Baik

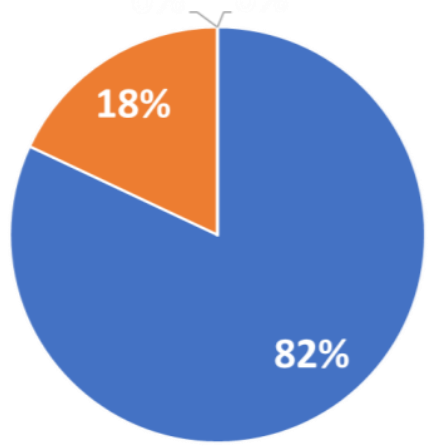

Fungsi Kepemimpinan Kepala Sekolah pada Lembaga Pendidikan Formal Yayasan Sunan Kalijogo Jabung

Deskripsi data tentang fungsi kepala sekolah pada penelitian ini dilakukan dengan menggunakan angket model $\mathrm{C}$ yang terdiri dari 10 pernyataan yang kemudian diukur dengan skor 1 sampai 5. Angket model C disebarkan kepada responden yaitu keempat kepala sekolah di lembaga pendidikan formal SD,SMP, SMA, dan SMK Sunan Kalijogo Jabung. Berdasarkan data yang diperoleh dari angket model C, diketahui bahwa dari total 4 responden sebanyak 3 responden atau $75 \%$ masuk pada kualifikasi Sangat Baik, lalu 1 responden atau 25\% masuk pada kualifikasi Baik, dan pada kualifikasi cukup dan rendah sebanyak 0 responden atau 0,00\%. Jadi mayoritas kepala sekolah di lembaga pendidikan formal SD,SMP, SMA, dan SMK Sunan Kalijogo Jabung telah melakukan fungsi kepemimpinannya sesuai dengan keadaan dan situasi pada lembaga yang dipimpinnya. 


\section{Syarat kepemimpinan Kepala Sekolah pada Lembaga Pendidikan Formal Yayasan Sunan Kalijogo Jabung}

Agar memahami tentang syarat kepala sekolah yang sesuai dengan karakteristik, situasi, dan keadaan lingkungan di Lembaga Pendidikan Formal Yayasan Sunan Kalijogo Jabung, maka di butuhkan deskripsi data tentang syarat kepemimpinan kepala sekolah. Untuk itu pada penelitian ini dibuat angket model D yang terdiri dari 10 item pernyataan dan diukur menggunakan skor 1 sampai 5, berdasarkan angket model $\mathrm{C}$ yang telah disebarkan kepada responden sebanyak 4 orang kepala sekolah pada Lembaga Pendidikan Formal Yayasan Sunan Kalijogo Jabung, dapat diketahui diketahui bahwa dari total 4 responden sebanyak 3 responden atau $75 \%$ sangat sesuai dengan syarat kepemimpinan yang dibutuhkan, lalu 1 responden atau 25\% sesuai dengan syarat kepemimpinan yang dibutuhkan, dan pada kualifikasi tidak sesuai sebanyak 0 responden atau 0,00\%. Jadi mayoritas kepala sekolah di lembaga pendidikan formal SD,SMP, SMA, dan SMK Sunan Kalijogo Jabung telah telah sesuai dengan syarat kepemimpinan yang dibutuhkan pada lembaga pendidikan formal SD, SMP, SMA, dan SMK Sunan Kalijogo Jabung.

\section{Tipe-tipe Kepemimpinan Kepala Sekolah pada Lembaga Pendidikan Formal Yayasan Sunan Kalijogo Jabung}

Tipe kepemimpinan yang sesuai juga dibutuhkan untuk dapat melaksanakan berbagai program pendidikan yang ada di lembaga pendidikan formal Sunan Kalijogo Jabung. Deskripsi data tentang tipe-tipe kepemimpinan kepala sekolah pada penelitian ini dibuat angket dengan model E yang terdiri dari 7 item pernyataan lalu diukur dengan menggunakan skor 1 sampai 5. Berdasarkan angket yang telah disebarkan kepada responden yakni 4 orang kepala sekolah pada Lembaga Pendidikan Formal Yayasan Sunan Kalijogo Jabung, dapat dipahami bahwa 4 responden atau 100\% telah memiliki kategori tipe kepemimpinan yang Sangat Sesuai di lembaga pendidikan formal Sunan Kalijogo Jabung, jadi bisa disimpulkan 
bahwa kepala sekolah di tiap lembaga pendidikan formal tersebut telah memiliki tipe kepimpinan yang dibutuhkan oleh lembaga pendidikan formal SD, SMP, SMA, dan SMK Sunan Kalijogo Jabung.

\section{Keterampilan Kepemimpinan Kepala Sekolah Lembaga Pendidikan Formal Yayasan Sunan Kalijogo Jabung}

Keterampilan kepemimpinan menjadi hal utama yang harus dimiliki oleh seorang kepala sekolah dalam melaksanakan kepemimpinannya pada lembaga pendidikan formal Sunan Kalijogo Jabung. Deskripsi data tentang tipe-tipe kepemimpinan kepala sekolah pada penelitian ini dibuat angket dengan model $\mathrm{F}$ yang terdiri dari 6 item pernyataan yang kemudian diukur menggunakan penskoran 1 sampai 5. Berdasarkan angket yang telah disebarkan kepada responden yakni 4 orang kepala sekolah pada Lembaga Pendidikan Formal Yayasan Sunan Kalijogo Jabung, dapat dipahami bahwa 2 responden atau 50\% telah memiliki kategori Keterampilan yang Sangat Baik dalam kepemimpinannya, dan 2 responden atau 50\% telah memiliki kategori Keterampilan yang Baik dalam kepemimpinannya di lembaga pendidikan formal Sunan Kalijogo Jabung, jadi bisa dipahami bahwa kepala sekolah di tiap lembaga pendidikan formal tersebut telah memiliki keterampilan kepemimpinan dalam menjalankan tugas dan tanggung jawabnya untuk memimpin lembaga pendidikan formal SD, SMP, SMA, dan SMK Sunan Kalijogo Jabung.

\section{E. PENUTUP}

\section{Kesimpulan}

Kepemimpinan Kepala Sekolah yang Efektif secara keseluruhan pada lembaga pendidikan formal SD, SMP, SMA, dan SMK Sunan Kalijogo Jabung dapat dinilai dalam kategori Sangat Baik. Jadi semua kepala sekolah telah memenuhi segala kriteria yang dibutuhkan oleh lembaga pendidikan formal tersebut dan juga memenuhi segala persyaratan yang menjadi acuan dasar kepemimpinan di tiap lembaga pendidikan formal Sunan Kalijogo Jabung. Tiap kepala sekolah pada semua lembaga juga telah 
memiliki keterampilan serta tipe kepemimpinan yang sangat sesuai dengan karakteristik, situasi, dan lingkungan yang ada dalam Yayasan Sunan Kalijogo Jabung. Melalu observasi langsung dan penyebaran beberapa angket serta dengan melakukan perhitungan dan analisis temuan data dalam pelaksanaan penelitian yang dilakukan oleh peneliti, maka dapat dipahami bahwa semua kepala sekolah pada tiap lembaga pendidikan formal telah memenuhi syarat sebagai seorang pemimpin dalam lembaga pemimpinan tersebut, serta juga telah memiliki loyalitas tinggi dan berbagai tipe-tipe kepemimpinan kepala sekolah secara khusus dalam Yayasan Sunan Kalijogo Jabung dengan kategori Sangat Baik.

Berdasarkan pada hasil penelitian yang telah dilakukan ini menunjukkan bahwa kepemimpinan yang dilakukan oleh tiap kepala sekolah dalam memimpin lembaga pendidikan formal Yayasan Sunan Kalijogo dinilai sangat bai dan layak menjadi seorang kepalasekolah. Namun masih ada beberapa hal yang kurang sesuai untuk dijadikan acuan bagi Yayasan Sunan Kalijogo Jabung agar dapat menjadi lebih baik lagi, yakni berkaitan dengan penerapan peraturan dan kebijakan yang sesuai dengan karakteristik lembaga dan juga semua tenaga pendidik dan kependidikan di lingkungan Yayasan Sunan Kalijogo Jabung. Hasil penelitian dapat digunakan sebagai bahan pertimbangan, penilaian, atau acuan dalam mengembangkan pola pengelolaan program sekolah dalam meningkatkan fungsi, tipe dan keterampilan kepemimpinan kepala sekolah di lembaga pendidikan formal Yayasan Sunan Kalijogo Jabung. Selain itu hasil penelitian juga bisa menjadi 1) bahan wacana bagi guru agar mampu meningkatkan profesionalisme guru untuk menjadi lebih baik lagi, 2) bahan pembanding dan penambah referensi demi pengembangan ilmu, terutama sumber daya manusia, dan 3) bahan pengetahuan bekal dan keterampilan di kemudian hari, serta dapat dijadikan bahan referensi untuk meningkatkan wawasan tentang kepemimpinan kepala sekolah yang efektif di lembaga pendidikan formal yang bernaung di bawah Yayasan Sunan Kalijogo Jabung. 


\section{DAFTAR PUSTAKA}

Ali, M. 1987. Penelitian Kependidikan Prosedur dan Strategi. Bandung: Angkasa.

Arikunto, S. 2006. Prosedur Penelitian Suatu Pendekatan Praktek. Jakarta: PT. Rineka Cipta.

Bungin, B. 2008. Metodologi Penelitian Kuantitatif: Komunikasi, Ekonomi, dan Kebijakan Publik serta Ilmi-Ilmu Sosial Lainnya. Jakarta: Kencana Prenada Media Group.

Hadi, S. 1987. Statistik II. Yogyakarta: YPFP UGM.

Hanurawan, F. 2002. Psikologi Sosial Terapan. Malang: Triumvat Press.

Indrafachrudi, S. 2006. Bagaimana Memimpin Sekolah yang Efektif. Bogor : Ghalia Indonesia.

Margono, Drs. (2004). Metode Penelitian Pendidikan. Jakarta : PT Rineke.

Riduwan. 2005. Skala Pengukuran Variabel-Variabel Penelitian. Bandung: Alfabeta.

Sugiono. 2010. Metode Penelitian Pendidikan. Bandung: Alfabeta.

Umar, H. 2004. Metode Penelitian untuk Skripsi dan Tesis Bisnis . Jakarta: PT Raja Grafindo Persada.

Wahyosumidjo. 2007. Kepemimpinan Kepala Sekolah. Jakarta: PT Raja Grafindo Persada.

Winardi, J. 2004. Manajemen Perilaku Organisasi. Jakarta: Prenada Media. 